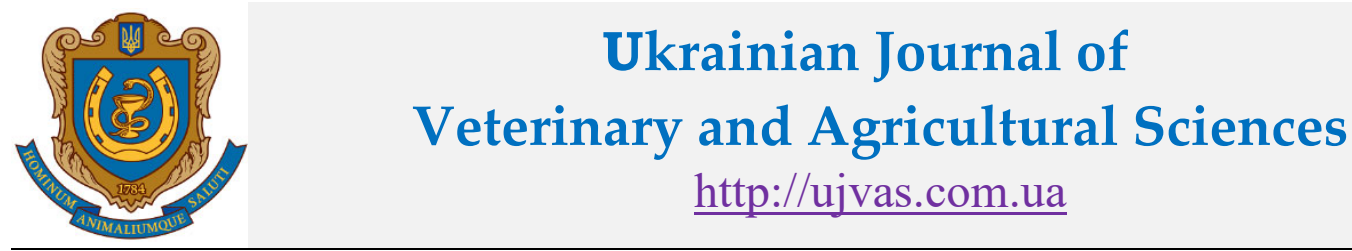

Stepan Gzhytskyi National University of Veterinary Medicine and Biotechnologies Lviv

original article $\mid$ UDC 636.2.082.355:637.115 $\mid$ doi: 10.32718/ujvas4-1.10

Volume 4

Number 1

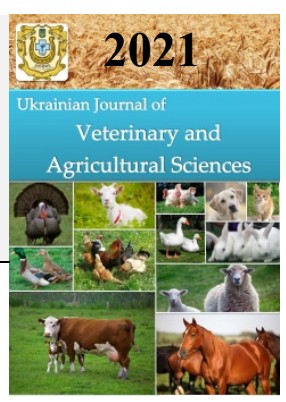

\title{
Bioenergetic and ethological features of the first-calf heifers of different genotypes
}

\author{
O. O. Borshch ${ }^{1}$, S. Yu. Ruban ${ }^{2}$, O. V. Borshch ${ }^{1}$, V. M. Polishchuk ${ }^{1}$ \\ ${ }^{1}$ Bila Tserkva National Agrarian University, pl. 8/1 Soborna, Bila Tserkva 09117 Ukraine \\ ${ }^{2}$ National University of Life and Environmental Science of Ukraine, Heroyiv Oborony Str., 15, Kyiv, 03041, Ukraine
}

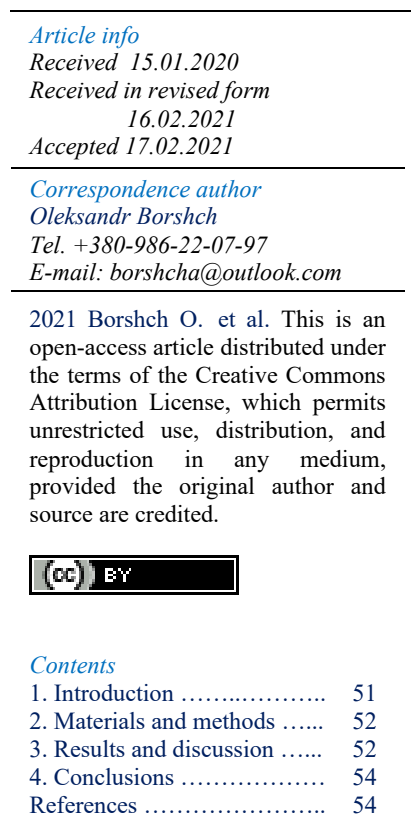

References ..................... 54

\begin{abstract}
The aim of this work was to study bioenergetic and ethological indicators in crossbred first-calf heifers compared to purebred first-calf heifers. The research was conducted on the first-calf heifers of Ukrainian Black-Pied dairy breed and first-generation crossbreeds obtained as a result of crossing with Brown Swiss breed, as well as, on the first-calf heifers of Ukrainian Red-Pied dairy breed and first-generation crossbreeds obtained as a result of crossing Ukrainian Red-Pied dairy with Montbéliarde breed. The purebred Black-and Red-Pied first-calf heifers prevailed over crossbreed first-calf heifers on the indicator of milk yield for 305 days of lactation by 106.45 and $218.36 \mathrm{~kg}$, respectively. Accordingly, the indicators of average daily milk yield were also higher by 0.35 and $0.72 \mathrm{~kg}$ and the indicators of average daily milk yield adjusted by $4 \%$ fat content per 0.15 and $0.16 \mathrm{~kg}$. At the same time, the indicator of average fat content in milk prevailed in crossbreeds of Black-Pied and Brown Swiss breed by $0.08 \%$ compared to purebred Black-Pied breeds, and in Red-Pied crossbreeds with Montbéliarde breed by $0.16 \%$ compared to purebred Red-Pied breeds. The purebred Black-Pied first-calf heifers had an advantage by $2.04 \mathrm{MJ}$ compared to crossbreeds, while the Red-Pied first-calf heifers had a slight advantage by $0.06 \mathrm{MJ}$ compared to crossbreed first-calf heifers on the indicator of daily cost of exchange energy (EE). The purebred Blackand Red-Pied first-calf heifers had higher cost of exchange energy allocated with milk compared to crossbreed first-calf heifers by 0.42 and 0.82 MJ. They also had higher cost of exchange energy rates for heat products by 0.79 and 0.25 MJ. According to the energy index indicator, purebred Black - and Red-Pied first-calf heifers prevailed over crossbreeds first-calf heifers by 0.16 and $0.07 \%$, respectively. The same trend was observed in relation to the productive index indicator. The purebred Black-and Red-Pied first-calf heifers had a slight advantage by 0.001 and $0.002 \mathrm{~kg}$ adjusted by $4 \%$ of milk fat content per $1 \mathrm{MJ}$. According to the indicators of daily behavioral reactions, no special differences between a purebred and crossbreed were found.
\end{abstract}

Key words: cross-breeding, first-calf heifers, productivity, bioenergetics, behavior, exchange energy.

\section{Citation:}

Borshch, O. O., Ruban, S. Yu., Borshch, O. V., \& Polishchuk, V. M. (2021). Bioenergetic and ethological features of the first-calf heifers of different genotypes. Ukrainian Journal of Veterinary and Agricultural Sciences, 4(1), 51-55.

\section{Introduction}

In the structure of livestock production, the most acute problem is increasing in milk production, the solution of which is associated with improving the genetic resources of domestic cattle breeds and increasing their productive longevity (Ruban et al., 2017). In this regard, domestic dairy breeds require improvement in the direction of genetic potential for growth, development and productivity (Bryant et al., 2007; Clasen et al., 2019; Clasen et al., 2020). The use of the world's gene pool for this purpose, which is expressed in the import of animals of various genetic breeding, creates certain problems of an adaptive nature to various natural and climatic conditions (Dezetter et al., 2017; Borshch et al., 2019; Ruban et al., 2020). Full realization of the genetic potential is possible only in favorable conditions of feeding and keeping. It is known that under the influence of different environmental conditions (feeding, care and keeping, features of use, etc.), the formation of traits is not the same in animals with approximately the same heredity (Hazel et al., 2017; Puppel et al., 2018; Shonka-Martin et al., 2019).

Holsteinized cattle, along with many positive characteristics, also have a number of problems associated with a decrease in reproduction level, productive longevity and product quality (Borshch et al., 2020). One of the methods for improving these characteristics of dairy cattle in commercial herds is crossbreeding (Tetens et al., 2014). It is a system of interbreeding, in which the offspring can be expected to have higher indicators of individual quantitative traits than in the parents due to their heterozygosity for many genes (Berry et al., 2014). In the United States, among improving breeds for Holstein breeds are the Jersey, Brown Swiss, Ayrshire and Montbéliarde and in the countries of the European Union and Scandinavia are the Swedish, Norwegian and Danish red breeds (Malchiodi et al., 2014). It was established that in crossbred animals of the first generation significantly improved such functional characteristics as productive longevity, qualitative 
composition of milk, reproduction indicators (Borshch et al., 2018).

It is known that the development of any organism feature is determined by heredity (genotype) and living conditions. The quantitative characteristics that include milk productivity and the qualitative composition of milk are usually judged by phenotype. A common condition for all metabolic reactions in ruminants is using energy, heat, the only source of which in the body is the adenosine monophosphate compound. In contrast to organizational and technological factors, biological factors are used much less in assessing the energy efficiency of food production. Therefore, the study of milk productivity at the level of energy consumption of the body, food activity and environmental influences has theoretical and practical significance.

The aim of this work was to study bioenergetic and ethological indicators in crossbred first-calf heifers compared to purebred first-calf heifers.

\section{Materials and methods}

The research was conducted on the first-calf heifers of Ukrainian Black-Pied dairy breed and first-generation crossbreeds obtained as a result of crossing with Brown Swiss breed in LLC ARE "Mykhailivske", in Mykhailivka village $\left(49^{\circ} 11^{\prime} 52^{\prime \prime} \mathrm{N}, 28^{\circ} 43^{\prime} 29^{\prime \prime}\right.$ E) of Vinnytsia district, Vinnytsia region, as well as, on the first-calf heifers of Ukrainian Red-Pied dairy breed and first-generation crossbreeds obtained as a result of crossing Ukrainian RedPied dairy with Montbéliarde breed in LLC "Azorel", in

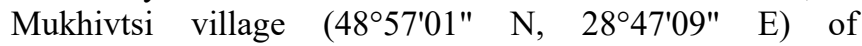
Nemyrivskyi district, Vinnytsia region. Two groups of purebred and crossbreed heifers were formed in both farms, one with the number of 25 (ALLC "Mykhailivske") and the other with 20 (LLC “Azorel”) heads in each. The same type of year-round cows feeding with complete feed mixtures is used in both farms.

The surface area of cows' bodies was determined by the Fox and Tylutki, 1998, method:

$$
\mathrm{SA}=0,09 \times \mathrm{SBW}^{0,67}
$$

Where SA is the surface area of the body $\mathrm{M}^{2}$;

SBW - live weight, $\mathrm{kg}$.

The daily cows behavior was studied according to the method to which during 2 consecutive days every 10 minutes in experimental groups, the number of cows were recorded which actively or passively consumed food, rested standing or lying near the feeder or on the litter, moved, consumed water during the observation period.

All data are presented as the means \pm standard error of the mean. Student's $t$-test was used to estimate statistical significance of the obtained values. Data were considered significant at $\mathrm{P}<0.05, \mathrm{P}<0.01, \mathrm{P}<0.001$.

\section{Results and discussion}

According to the results of Table 1, the purebred Blackand Red-Pied first-calf heifers prevailed over crossbreed first-calf heifers on the indicator of milk yield for 305 days of lactation by 106.45 and $218.36 \mathrm{~kg}$. Accordingly, the average indicators of daily milk yield was also higher by 0.35 and $0.72 \mathrm{~kg}$ and the average indicators of daily milk yield adjusted by $4 \%$ fat content per 0.15 and $0.16 \mathrm{~kg}$. At the same time, the indicator of average fat content in milk prevailed over in crossbreeds of Black-Pied and Brown Swiss breeds by $0.08 \%$ compared to purebred Black-Pied breeds, and in Red-Pied crossbreeds with the Montbéliarde breed by $0.16 \%$ compared to purebred Red-Pied breeds. According to the indicator of average live weight, the purebred BlackPied first-calf heifers prevailed over crossbreed first-calf heifers by $18.35 \mathrm{~kg}$, while Red-Pied first-calf heifers were inferior to crossbreed first-calf heifers by $21.22 \mathrm{~kg}$.

Table 1

Productive signs of first-calf heifers of various origins $(\mathrm{M} \pm \mathrm{m})$

\begin{tabular}{lcccc}
\hline & \multicolumn{4}{c}{ Breed, pedigree } \\
\cline { 2 - 5 } \multicolumn{1}{c}{ Indicator } & Black-Pied dairy & $\begin{array}{c}1 / 2 \text { Black-Pied dairy and } \\
1 / 2 \text { Brown Swiss }\end{array}$ & Red-Pied dairy & $\begin{array}{c}1 / 2 \text { Red-Pied dairy and } \\
1 / 2 \text { Montbéliarde }\end{array}$ \\
\cline { 2 - 5 } & $\mathrm{n}=25$ & $\mathrm{n}=25$ & $\mathrm{n}=20$ & $\mathrm{n}=20$ \\
\hline Live weight, $\mathrm{kg}$ & $507.95 \pm 7.17$ & $489.60 \pm 6.58$ & $510.39 \pm 6.25$ & $531.61 \pm 7.54^{*}$ \\
Milk yield for 305 days of lactation, $\mathrm{kg}$ & $6302.81 \pm 33.29$ & $6196.36 \pm 28.43^{* * *}$ & $6478.20 \pm 38.31$ & $6259.84 \pm 33.72^{* * *}$ \\
Average daily milk yield, kg & $20.66 \pm 0.10$ & $20.31 \pm 0.09^{*}$ & $21.24 \pm 0.17$ & $20.52 \pm 0.08^{* *}$ \\
Average fat content in milk, $\%$ & $3.74 \pm 0.03$ & $3.82 \pm 0.09$ & $3.73 \pm 0.05$ & $3.89 \pm 0.06^{* *}$ \\
Average daily milk yield is adjusted by & $16.59 \pm 0.34$ & $16.44 \pm 0.28$ & $17.02 \pm 0.26$ & $16.86 \pm 0.21$ \\
4\% fat content, $\mathrm{kg}$ & $5.84 \pm 0.29$ & $5.71 \pm 0.23$ & $5.86 \pm 0.19$ & $6.03 \pm 0.27$ \\
Body surface area, $\mathrm{M}^{2}$ & & &
\end{tabular}

Note: $* \mathrm{P}<0.05 ; * * * \mathrm{P}<0.001$ as compared with Black-Pied dairy and Red-Pied dairy groups

In highly productive herds, cows should resting on average $50 \%$ of their time per day, $21 \%$ of eating feed, $4 \%$ of drinking, etc (Ruban et al., 2017). Special importance is given to rest in the lying position. The milk secretion improves during lying down because more blood passes through the udder. It was established that purebred Black- and Red-Pied first-calf heifers slightly prevailed over crossbreed first-calf heifers on indicator in the lying down position by 1.7 and $0.3 \%$ and feed consumption by 0.1 and $0.3 \%$, respectively (fig. 1). Crossbreed first-calf heifers had slightly higher values for standing and motor behavior. 


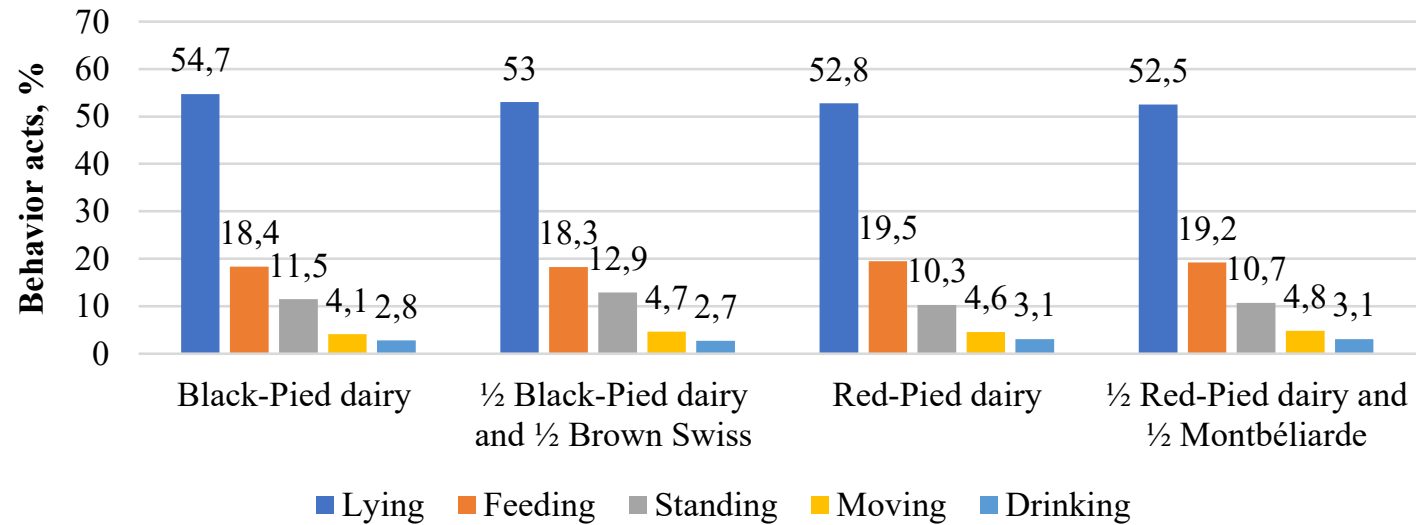

Fig.1. The main elements of the daily behavior of first-calf heifers of different origins

According to the indicator of daily cost of exchange energy (EE), purebred Black-Pied first-calf heifers had an advantage by $2.04 \mathrm{MJ}$ compared to crossbreeds, while RedPied first-calf heifers had a slight advantage by $0.06 \mathrm{MJ}$ compared to crossbreed first-calf heifers (Table 2).

The purebred Black-and Red-Pied first-calf heifers had higher cost of exchange energy allocated with milk compared to crossbreed first-calf heifers by 0.42 and 0.82 MJ. They also had higher cost of exchange energy rates for heat products by 0.79 and $0.25 \mathrm{MJ}$. It was established that the cost of exchange energy for muscle activity prevailed over crossbreed first-calf heifers. Thus, in crossbreeds of Black-Pied and Brown Swiss cows, this indicator was higher by $0.02 \mathrm{MJ}$, and in crossbreeds of Red-Pied and Montbéliarde cows by $0.04 \mathrm{MJ}$ compared to purebred cows. According to the indicator of basic metabolism, which directly depends on the body weight of animals, purebred Black-Pied first-calf heifers prevailed over crossbreeds by $0.85 \mathrm{MJ}$, and crossbreeds of Red-Pied and Montbéliarde cows prevailed over purebred first-calf heifers by $0.97 \mathrm{MJ}$.

Table 2

Structure of daily cost of exchange energy $(\mathrm{M} \pm \mathrm{m})$

\begin{tabular}{lcccc}
\hline & \multicolumn{4}{c}{ Breed, pedigree } \\
\cline { 2 - 5 } \multicolumn{1}{c}{ Indicator } & Black-Pied dairy & $\begin{array}{c}1 / 2 \text { Black-Pied dairy and } \\
1 / 2 \text { Brown Swiss }\end{array}$ & Red-Pied dairy & $\begin{array}{c}1 / 2 \text { Red-Pied dairy and } 1 / 2 \\
\text { Montbéliarde }\end{array}$ \\
\cline { 2 - 5 } & $\mathrm{n}=25$ & $\mathrm{n}=25$ & $\mathrm{n}=20$ & $\mathrm{n}=20$ \\
\hline Exchange energy, MJ & $139.77 \pm 2.33$ & $137.73 \pm 2.18$ & $141.88 \pm 1.79$ & $141.82 \pm 1.67$ \\
Basic metabolism, MJ & $31.35 \pm 0.24$ & $30.50 \pm 0.21^{*}$ & $31.47 \pm 0.26$ & $32.44 \pm 0.32^{*}$ \\
- by 1 kg of live weight, MJ & $0.061 \pm 0.0006$ & $0.062 \pm 0.0005$ & $0.061 \pm 0.0004$ & $0.061 \pm 0.0003$ \\
- by 1 kg of milk, MJ & $1.51 \pm 0.0014$ & $1.50 \pm 0.0011^{* * *}$ & $1.48 \pm 0.0015$ & $1.58 \pm 0.0021^{* * *}$ \\
- in \% to exchange energy & 22.4 & 22.1 & 22.3 & 22.9 \\
Exchange energy allocated with milk, & $61.43 \pm 1.23$ & $61.01 \pm 1.28$ & $63.06 \pm 1.57$ & $62.24 \pm 1.41$ \\
MJ & $0.12 \pm 0.0009$ & $0.12 \pm 0.0013$ & $0.12 \pm 0.0017$ & $0.11 \pm 0.0015^{* * *}$ \\
- by 1 kg of live weight, MJ & 44 & 44,3 & 44,4 & 43.9 \\
- in \% to exchange energy & $5.46 \pm 0.07$ & $5.48 \pm 0.07$ & $5.32 \pm 0.11$ & $5.36 \pm 0.10$ \\
Cost of exchange energy on muscle & & & $0.250 \pm 0.0027$ & $0.261 \pm 0.0034^{*}$ \\
activity, MJ & $0.264 \pm 0.0037$ & $0.269 \pm 0.0038$ & 3.7 & 3.8 \\
- by 1 kg of milk, MJ & 3.9 & 4.0 & $42.03 \pm 0.55$ & $41.78 \pm 0.46$ \\
- in \% to exchange energy & $41.53 \pm 0.74$ & $40.74 \pm 0.62$ & & \\
Cost of exchange energy for heat & & & \\
products, MJ & $0.081 \pm 0.0020$ & $0.083 \pm 0.0009$ & $0.082 \pm 0.0014$ & $0.078 \pm 0.0009$ \\
- by 1 kg of live weight, MJ & $7.11 \pm 0.11$ & $7.13 \pm 0.14$ & $7.17 \pm 0.09$ & $6.92 \pm 0.06$ \\
- by 1 M ${ }^{2}$ of body surface area, MJ & $2.01 \pm 0.05$ & $2.00 \pm 0.04$ & $1.97 \pm 0.02$ & $2.03 \pm 0.03$ \\
- by 1 kg of milk, MJ & 29.7 & 29.6 & 29.6 & 29.4 \\
- in \% to exchange energy &
\end{tabular}

Note: ${ }^{*} \mathrm{P}<0.05 ; * * * \mathrm{P}<0.001$ as compared with Black-Pied dairy and Red-Pied dairy groups

The amount of energy consumed per unit of livestock production and for supporting the body's vital functions allows us to determine the bioenergetic efficiency of various production technologies and characterizes their compliance with the biological needs of animals. Bioenergetic assessment of animals reflects the harmony of their development, so it is integrated and combines external, productive, technological and other features of the body. Therefore, in recent decades bioenergetic assessment has been used to evaluate technologies and technological processes and in selection during evaluating breeds. The purebred Black-Pied first-calf heifers prevailed over crossbreed first-calf heifers on indicator of energy cost per $1 \mathrm{~kg}$ of 4 th milk by $0.04 \mathrm{MJ}$, and energy cost per $1 \mathrm{MJ}$ of milk energy by $0.13 \mathrm{MJ}$ (table). However, the crossbreed first-calf heifers obtained from crossing Black-Pied and Brown Swiss breeds prevailed according to the indicator of the energy allocated with milk per $1 \mathrm{~kg}$ of live weight. The opposite results were observed in the other part of the experiment. The crossbreeds of Red-Pied and Montbéliarde breeds were prevailed by $0.09 \mathrm{MJ}$ to purebred 
Red-Pied breeds on the indicator of energy cost per $1 \mathrm{~kg}$ of $4 \%$ of milk and by $0.03 \mathrm{MJ}$ of energy cost per $1 \mathrm{MJ}$ of milk energy. The purebred Red-Pied cows had higher indicators of energy allocated with milk per $1 \mathrm{~kg}$ of live weight by $0.025 \mathrm{MJ}$. According to the energy index indicator, which shows what part of net costs of energy feed is converted into milk energy, the purebred Black-and Red - Pied first-calf heifers prevailed over crossbreed first-calf heifers by 0.16 and $0.07 \%$. The same trend was observed in relation to the productive indicator index (milk production adjusted by $4 \%$ fat content, based on $1 \mathrm{MJ}$ of net energy). The purebred
Black-and Red-Pied first-calf heifers had a slight advantage by 0.001 and $0.002 \mathrm{~kg}$ of milk fat content adjusted by $4 \%$ per $1 \mathrm{MJ}$.

The research of feed dry matter consumption have shown that crossbreed first-calf heifers of Black-Pied and Brown Swiss breeds prevailed over purebred first-calf heifers by $0.14 \mathrm{~kg}$, and Red-Pied and Montbéliarde first-calf heifers by $0.07 \mathrm{~kg}$ (table.). Feed conversion was higher in purebred Black- and Red-Pied first-calf heifers by 0.025 and $0.040 \mathrm{~kg}$ of milk $/ \mathrm{kg}$ of feed dry matter, respectively.

Table 3

Bioenergetic characteristics of the first-calf heifers $(\mathrm{M} \pm \mathrm{m})$

\begin{tabular}{|c|c|c|c|c|}
\hline \multirow{3}{*}{ Indicator } & \multicolumn{4}{|c|}{ Breed, pedigree } \\
\hline & Black-Pied dairy & $\begin{array}{l}1 / 2 \text { Black-Pied dairy and } \\
1 / 2 \text { Brown Swiss }\end{array}$ & Red-Pied dairy & $\begin{array}{l}1 / 2 \text { Red-Pied dairy and } 1 / 2 \\
\text { Montbéliarde }\end{array}$ \\
\hline & $\mathrm{n}=25$ & $\mathrm{n}=25$ & $\mathrm{n}=20$ & $\mathrm{n}=20$ \\
\hline Live weight, $\mathrm{kg}$ & $106.99 \pm 1.54$ & $104.08 \pm 1.39$ & $107.38 \pm 1.43$ & $110.71 \pm 1.59$ \\
\hline $\begin{array}{l}\text { Energy cost per } 1 \mathrm{~kg} \text { of } 4 \% \text { of } \\
\text { milk, MJ }\end{array}$ & $6.28 \pm 0.02$ & $6.24 \pm 0.01$ & $6.22 \pm 0.01$ & $6.31 \pm 0.02$ \\
\hline $\begin{array}{l}\text { Energy cost per } 1 \mathrm{MJ} \text { of milk } \\
\text { energy, MJ }\end{array}$ & $1.695 \pm 0.004$ & $1.682 \pm 0.004$ & $1.681 \pm 0.004$ & $1.711 \pm 0.006^{* * *}$ \\
\hline $\begin{array}{l}\text { Energy allocated with milk per } 1 \\
\mathrm{~kg} \text { of live weight, MJ }\end{array}$ & $0.574 \pm 0.004$ & $0.586 \pm 0.004^{* * *}$ & $0.587 \pm 0.003$ & $0.562 \pm 0.002^{* * *}$ \\
\hline Energy index, \% & 58.94 & 58.78 & 59.50 & 58.43 \\
\hline $\begin{array}{l}\text { Productive index, } \mathrm{kg} \text { MAF (4\%)/ } \\
\text { MJ }\end{array}$ & 0.190 & 0.189 & 0.192 & 0.189 \\
\hline
\end{tabular}

Note: $* \mathrm{P}<0.05 ; * * * \mathrm{P}<0.001$ as compared with Black-Pied dairy and Red-Pied dairy groups

Table 4

Duration of feed and dry matter consumption in first-calf heifers of the studied breeds $(\mathrm{M} \pm \mathrm{m})$

\begin{tabular}{lccc}
\hline \multirow{2}{*}{ Indicator } & \multicolumn{2}{c}{ Breed, pedigree } \\
\cline { 2 - 4 } & Black-Pied dairy & $\begin{array}{c}1 / 2 \text { Black-Pied dairy } \\
\text { and } 1 / 2 \text { Brown Swiss }\end{array}$ & $\begin{array}{c}\text { Red-Pied dairy } \\
1 / 2 \text { Red-Pied dairy and } \\
1 / 2 \text { Montbéliarde }\end{array}$ \\
\cline { 2 - 4 } & $\mathrm{n}=25$ & $\mathrm{n}=25$ & $\mathrm{n}=20$ \\
\hline Dry matter consumption per day, $\mathrm{kg}$ & $19.78 \pm 0.15$ & $19.64 \pm 0.14$ & $20.12 \pm 0.28$ \\
Conversion, $\mathrm{kg}$ of milk $/ \mathrm{kg}$ of dry matter & 1.04 & 1.03 & $20.05 \pm 0.23$ \\
1.02 & 1.05 \\
\hline
\end{tabular}

\section{Conclusions}

It was established that purebred Black- and Red-Pied first-calf heifers prevailed over crossbreed first-calf heifers on the indicator of milk yield for 305 days of lactation, daily cost of exchange energy and values of productive and energy indices. At the same time, the average fat content in milk prevailed in crossbreeds of Black-Pied and Brown Swiss breeds by $0.08 \%$ compared to purebred Black-Pied breed, and in Red-Pied crossbreeds with Montbéliarde breed by $0.16 \%$ compared to purebred Red-Pied breed. According to the indicators of daily behavioral reactions, no special differences between purebred and crossbreed were found.

\section{Conflict of interest}

The authors declare that there is no conflict of interest.

\section{References}

Berry, D. P., Wall, E., \& Pryce, J. E. (2014). Genetics and genomics of reproductive performance in dairy and beef cattle. Animal, 8(1), 105-121. doi: 10.1017/S1751731114000743.

Borshch, A. A., Ruban, S., Borshch, A. V., \& Babenko, O. (2019). Effect of three bedding materials on the microclimate condi- tions, cows behavior and milk yield. Polish Journal of Natural Sciences, 34, 19-31.

Borshch, A. A., Borshch, A. V., Lutsenko, M. M., Merzlov, S. V., Kosior, L. T., Lastovska, I. A., \& Pirova, L. V. (2018). Amino acid and mineral composition of milk from local Ukrainian cows and their crossbreedings with Brown Swiss and Montbeliarde breeds. Journal of the Indonesian Tropical Animal Agriculture, 43(3), 238-246. doi: 10.14710/jitaa.43.3.238-246.

Borshch, O. O., Gutyj, B. V., Sobolev, O. I., Borshch, O. V., Ruban, S. Yu., Bilkevich, V. V., Dutka, V. R., Chernenko, O. M., Zhelavskyi, M. M., \& Nahirniak, T. (2020). Adaptation strategy of different cow genotypes to the voluntary milking system. Ukrainian Journal of Ecology, 10(1), 145-150. doi: 10.15421/2020_23.

Bryant, J. R., López-Villalobos, N., Pryce, J.E., Holmes, C. W., Johnson, D. L., \& Garrick, D. J. (2007). Short communication: Effect of environment on the expression of breed and heterosis effects for production traits. Journal of Dairy Science, 90, 1548-1553. doi: 10.3168/jds.S0022-0302(07)71640-5.

Clasen, J. B., Fikse, W.F., Kargo, M., Rydhmer, L., Strandberg, E., \& Østergaard, S. (2020). Economic consequences of dairy crossbreeding in conventional and organic herds in Sweden. Journal of Dairy Science, 103, 514-528. doi: 10.3168/jds.2019-16958.

Clasen, J. B., Fogh, A., \& Kargo, M. (2019). Differences between performance of F1 crossbreds and Holsteins at different production levels. Journal of Dairy Science, 102, 436-441. doi: 10.3168/jds.2018 -14975. 
Dezetter, C., Bareille, N., Billon, D., Côrtes, C., Lechartier, C., \& Seegers, H. (2017). Changes in animal performance and profitability of Holstein dairy operations after introduction of crossbreeding with Montbéliarde, Normande, and Scandinavian Red. Journal of Dairy Science, 100 (10), 8239-8264. doi: 10.3168/jds.2016-11436.

Fox, D.G. \& Tylutki, T.P. (1998). Accounting for the Effects of Environment on the Nutrient Requirements of Dairy Cattle. Journal of Dairy Science, 81, 3085-3095. doi: 10.3168/jds.S00220302(98)75873-4

Hazel, A.R., Heins, B.J., \& Hansen, L.B. (2017). Fertility, survival, and conformation of Montbéliarde $\times$ Holstein and Viking Red $\times$ Holstein crossbred cows compared with pure Holstein cows during first lactation in 8 commercial dairy herds. Journal of Dairy Science, 100(11), 9447-9458. doi: 10.3168/jds.201712824.

Kargo, M., Clasen, J.B., Nielsen, H.M., Byskov, K., \& Norberg, E. (2021). Short communication: Heterosis and breed effects for milk production and udder health traits in crosses between Danish Holstein, Danish Red, and Danish Jersey. Journal of Dairy Science, 104(1), 678-682. doi: 10.3168/jds.2019-17866.

Malchiodi, F., Cecchinato, A., \& Bittante, G. (2014). Fertility traits of purebred Holsteins and 2- and 3-breed crossbred heifers and cows obtained from Swedish Red, Montbéliarde, and Brown Swiss sires. Journal of Dairy Science, 97, 7916-7926. doi: $10.3168 /$ jds.2014-8156.
Puppel, K., Bogusz, E., Gołębiewski, M., Nałęcz-Tarwacka, T., Kuczyńska, B., Slósarz, J., Budziński, A., Solarczyk, P., Kunowska-Slósarz, M., \& Przysucha, T. (2018). Effect of Dairy Cow Crossbreeding on Selected Performance Traits and Quality of Milk in First Generation Crossbreds. Journal of Food Science, 83 (1), 229-236. doi: 10.1111/1750-3841.13988.

Ruban, S. Yu., Borshch, O. V., \& Borshch, O. O. (2017). Suchasni tekhnolohiyi vyrobnytstva moloka. (osoblyvosti ekspluatatsiyi, tekhnolohichni rishennya, eskizni proekty) [Modern milk production technologies. (peculiarities of operation, technological decisions, sketch designs)]. Kharkiv: STYLIZDAT (in Ukrainian).

Ruban, S., Borshch, O. O., Borshch, O. V., Orischuk, O., Balatskiy, Y., Fedorchenko, M., Kachan, A., \& Zlochevskiy, M. (2020). The impact of high temperatures on respiration rate, breathing condition and productivity of dairy cows in different production systems. Animal Science Papers and Reports, 38(1), 61-72. URL: https://www.cabdirect.org/cabdirect/abstract/20203167447.

Shonka-Martin, B.N., Heins, B.J., \& Hansen, L.B. (2019). Threebreed rotational crossbreds of Montbéliarde, Viking Red, and Holstein compared with Holstein cows for feed efficiency, income over feed cost, and residual feed intake. Journal of Dairy Science, 102(4), 3661-3673. doi: 10.3168/jds.2018-15682.

Tetens, J., Thaller, G., \& Krattenmacher, N. (2014). Genetic and genomic dissection of dry matter intake at different lactation stages in primiparous Holstein cows. Journal of Dairy Science, 97, 520-531. doi: 10.3168/jds.2013-7301. 